\title{
COMMENTARY
}

\section{FREE SPEECH WITHOUT ROMANCE: PUBIIC CHOICE AND THE FIRST AMENDMENT}

\author{
Daniel A. Farber
}

\section{INTRODUCTION}

What is special about speech? ${ }^{1}$ Why is it exempt from various types of regulation routinely applied to other activities? $?^{2}$ For instance, why are there special restrictions on liability for harmful speech ${ }^{3}$ and a unique constitutional right to use certain government property for communication, but not for any other purpose? ${ }^{4}$

* Henry J. Fletcher Professor of Law, University of Minnesota. I would like to thank Dianne Farber, Phil Frickey, Michael Paulsen, and Suzanna Sherry for their helpful comments on an earlier draft, as well as Doug Winthrop and Garry Kaufman for their research assistance.

${ }^{1}$ Several commentators have surveyed the efforts to answer this question. See, e.g., FREDERICK SCHAUER, FREE SPEECH: A PHILOSOPHICAL INQUIRY 80-86 (Ig82) (surveying free speech theories and endorsing a "negative" theory of the First Amendment); LAURENCE H. TRIBE, AMERICAN CONSTITUTIONAL LAW $\$$ I2-1, at $785-89$ (2d ed. 1988) (rejecting any single theory of freedom of expression); Lawrence Alexander \& Paul Horton, The Impossibility of a Free Speech Principle, 78 Nw. U. L. REv. I319 (1983); Ronald A. Cass, Commercial Speech, Constitutionalism, Collective Choice, 56 U. CIN. L. REV. I3I7, I322-45 (I988) (categorizing theories of speech regulation as ontological, economic, or constitutional); and Daniel A. Farber \& Philip P. Frickey, Practical Reason and the First Amendment, 34 UCLA L. REv. 1615, I617$56\left(x_{987}\right)$ (surveying and critiquing "foundational" First Amendment theories and advocating "practical reason" as an alternative).

${ }^{2}$ Consider, for example, a rule forbidding distribution of anonymous pamphlets, or one prohibiting door-to-door solicitation by organizations that do not spend at least $75 \%$ of collections on "charitable activities." The Court struck down such rules in Talley v. California, 362 U.S. 6o, 65 (1960), and Village of Schaumburg v. Citizens for a Better Env't, 444 U.S. 620, 622 (1980). Yet regulations such as these would be readily accepted forms of consumer protection if speech were not involved.

${ }^{3}$ See, e.g., Hustler Magazine, Inc. v. Falwell, 485 U.S. 46, 56-57 (1988) (holding that tort damages for a published parody of a public figure are available only for false statements of fact made with "actual malice"); New York Times Co. v. Sullivan, 376 U.S. $254,283-84$ (I964) (holding that damages for libel of public officials acting in their official capacity require proof of "actual malice").

4 See, e.g., United States v. Grace, 461 U.S. I7I, 183-84 (1983) (holding unconstitutional a statute prohibiting the use of the sidewalks around the Supreme Court building for purposes of peaceful picketing and leaffetting); see also Daniel A. Farber \& John E. Nowak, The Misleading Nature of Public Forum Analysis: Content and Context in First Amendment Adjudication, 70 VA. L. REV. I $219,1235-45$ (1984) (formulating a structured balancing test to review government regulations on speech); Robert C. Post, Between Governance and Management: The History and Theory of the Public Fonim, 34 UCLA L. REV. 1713, 1718-58, 1784-1809 (1987) (reviewing the development and application of public forum doctrine and distinguishing between nonpublic and public forums through a management-governance dichotomy). See generally Perry Educ. 
As Steven Shiffrin emphasizes in his recent book on the First Amendment, ${ }^{5}$ one way to answer these questions is to celebrate the Romantic ideals of self-expression and self-realization. ${ }^{6}$ Although that is undoubtedly a valuable perspective, this Commentary will explore a different and very unromantic understanding of the First Amendment's protection of speech. This understanding derives from public choice theory - that is, the application of economics methodology to political institutions. ${ }^{7}$

The crucial insight of public choice theory is that, because information is a public good, it is likely to be undervalued by both the market and the political system. ${ }^{8}$ Individuals have an incentive to "free ride" because they can enjoy the benefits of public goods without helping to produce those goods. Consequently, neither market demand nor political incentives fully capture the social value of public goods such as information. Our polity responds to this undervaluation of information by providing special constitutional protection for information-related activities. This simple insight explains a surprising amount of First Amendment doctrine.

This Commentary is not the first effort to understand the economics of the First Amendment. ${ }^{9}$ In particular, the connections between

Ass'n v. Perry Local Educators' Ass'n, 460 U.S. 37, 45-46 (1983) (explaining the difference between levels of access to public forums and to other types of public property).

${ }^{5}$ See Steven H. Shiffrin, The First amendient, Democracy, and Romance (iggo).

${ }^{6}$ See id. at $147-69$. For other important discussions of self-expression and self-realization as central First Amendment values, see C. EdwIN BAKER, HuMan LIBERTy AND FREedom of Speech 47-54 (1989); and Martin H. Redish, Freedom of Expression: A Critical ANALYSIS $9-40$ (Ig\$4).

'See generally Daniel A. Farber \& Philip P. Frickey, Law and Public Choice: A CRITICAL INTRODUCTION I-II (I99I) (surveying the relevance of public choice to legal scholarship).

8 The term "information" as used here is to some degree a metaphor because valuable speech does not necessarily communicate information in the sense of new data. For example, much of the sciences (particularly mathematics) consists of new ways of thinking about existing data. Technically, most works of mathematics do not provide new "information" - a smart enough person could immediately grasp all the theorems by reading the axioms and definitions. Obviously, this is true of many forms of argument in the humanities and social sciences and of the less tangible way in which new concepts and ideas enter our discourse through the general culture. Thus, "information," as used here, includes all intellectually useful material such as ideas and theories as well as facts.

9 Aaron Director and Ronald Coase opened this field of inquiry with several articles challenging the conventional wisdom that speech deserves greater protection than other activities. They argued that the government is as likely to overregulate other activities as it is to overregulate speech and that various economic activities may have as much importance to individual well-being as does speech. See R. H. Coase, Advertising and Free Speech, 6 J. LEGal Stud. I, I-5 (1977); R. H. Coase, The Market for Goods and the Market for Ideas, 64 AM. ECoN. Rev. 384, 386-90 (1974); Aaron Director, The Parity of the Economic Market Place, 7 J.L. \& Econ. I, 6-10 (1964); see also Cass, supra note I, at ${ }_{335}$ (discussing the argument presented by Coase and Director that the "market of ideas" is more protected from inefficient regulation than is the market for goods). The theory presented here attempts to use the economic perspective to rebut 
free speech and the attributes of information as a public good have not gone unnoticed. ${ }^{10}$ Previous scholarship, however, has not systematically explored the implications of this connection for First Amendment doctrine; rather, it has used it merely as one of a battery of economic arguments about freedom of speech. ${ }^{11}$ The public good attributes of information have been deployed as a strong policy argument against regulating speech, but they have not been used to explain why this policy should be enshrined in the Constitution and not left to legislatures. The public good theory deserves a more central analytical role. This Commentary attempts to fill the gap in analysis by showing that information is especially vulnerable in the political process precisely because it has the attributes of a public good.

Part II sketches the basic economics of information and its bearing on First Amendment issues. In Part III, the theory is used to explain why some types of communication are at the core of First Amendment protection while others are at the periphery or are entirely unprotected. Part IV then uses the theory to account for some specific First

the argument that other activities have just as much value as speech and are equally prone to overregulation by the government.

${ }^{10}$ See Richard A. Posner, Free Speech in an Economic Perspective, 20 SuFfolk U. L. Rev. I, 19-24, 36-39 (rg86). Judge Posner modifies and applies Judge Hand's Dennis formula, see United States v. Dennis, r83 F.2d 20I, 2 I2 (2d Cir. 1950), aff'd, 34I U.S. 494 (I95I), for determining when the government is justified in regulating speech. See Posner, supra, at 8-9. A counterpart to his negligence formula, Hand's free speech formula postulates that government should restrict speech only if the "gravity of the 'evil" discounted by its probability is greater than the social cost of regulating the speech. Id . at 8 (citing Dennis, I8 3 F.2d at 212). Posner argues that, to assess the cost of suppressing particular expression, one must consider whether the expression has the attributes of a public good. See id. at 19-20. Government restrictions on such expression, Posner contends, exacerbate the problems of expression as a public good and are highly suspect under Hand's cost-benefit analysis. See id. at 20-22. But see Peter J. Hammer, Note, Free Speech and the "Acid Bath": An Evaluation and Critique of Judge Richard Posner's Economic Interpretation of the First Amendment, 87 MrcH. L. REv. 499, 527-28 (I988) (arguing that the risk-of-error factor in Posner's formulation could significantly detract from the value of his insight regarding the public good nature of certain types of communication).

Ronald Cass incorporates Posner's theory of market robustness in his quest for ordering principles that will specify the proper level of First Amendment protection to be afforded different categories of speech. See Cass, supra note I, at ${ }_{1364-73}$. Cass argues that concern for official bias and intolerance is at the root of the First Amendment's protection of free expression. See id. at $\mathbf{1 3 5}^{2}$. The effects of that bias are worse when speech has the attributes of a public good. See id. at $\mathrm{I} 368$.

11 Judge Posner focuses on an expanded Dennis formula as a method for achieving economically efficient regulation of speech. The nature of the particular information market is just one element in Posner's formulation. See Posner, supra note 10, at 9-24. On the cost side of the equation, Posner considers not only the amount of speech suppressed, but also the value of that speech. See id. at 9. On the benefits side of the equation, Posner devotes a great deal of attention to the probability and magnitude of harm "if the speech in question is allowed" that is, if governmental regulation is absent. Id. at 29-36. In Cass's analysis, the public good nature of information similarly serves as only one factor in assessing the harmfulness of government bias. See supra note ro. 
Amendment doctrines. Part $\mathrm{V}$ concludes with some thoughts about the implications of the theory regarding the potential benefits of promoting self-expression as a societal value.

Many readers are undoubtedly skeptical about whether economic analysis can provide any useful insight into the First Amendment. The First Amendment seemingly involves deep philosophical issues far beyond the ken of economics. Moreover, there is no strong reason to suppose that any one unified theory - economic, philosophical, or otherwise - underlies the First Amendment. ${ }^{12}$ In response to this skepticism, two comments are in order.

First, this Commentary is by no means intended as an exercise in reductionism. Public choice theory is useful, but it cannot purport to be more than a partial explanation for political behavior; ${ }^{13}$ any particular application of public choice theory can claim no greater force. The values underlying the First Amendment undoubtedly go beyond economic efficiency. The inherent value of self-expression should not be dismissed as an important basis for freedom of speech. ${ }^{14}$ For example, it is questionable whether a satisfactory economic explanation can be given for protecting nonrepresentational art or instrumental music, which have no clear informational content. Nevertheless, it is remarkable how much of free speech doctrine can be defended without imputing any unique value to the act of expression.

Second, First Amendment jurisprudence and economics do share an important assumption. Government regulation of speech is often based on the premise that people respond irrationally to certain ideas or types of information. Skepticism regarding this premise is central to modern First Amendment doctrine. ${ }^{15}$ The First Amendment is based on the belief that people will make better decisions if they are more fully informed. Economics shares the First Amendment's optimistic, Enlightenment view of human rationality. Although the economic model is subject to criticism, ${ }^{16}$ it resembles traditional First

12 See generally Farber \& Frickey, supra note I, at $1639-45$ (criticizing the concept of a grand or "foundational" theory of the First Amendment).

${ }^{13}$ See FARBER \& FrICKEY, supra note 7 , at $4-5$.

I4 See sources cited supra note 6 .

15 As the Supreme Court has said:

There is .... an alternative to this highly paternalistic approach. That alternative is to assume that this information is not in itself harmful, that people will perceive their own best interests if only they are well enough informed, and that the best means to that end is to open the channels of communication rather than to close them. . . . But the choice among these alternative approaches is not ours to make .... It is precisely this kind of choice, between the dangers of suppressing information, and the dangers of its misuse if it is freely available, that the First Amendment makes for us.

Virginia State Bd. of Pharmacy v. Virginia Citizens Consumer Council, Inc., 425 U.S. 748,770 (I976).

16 The economist's conception of rationality may be at once too narrow, because it assumes that people can reason about their choice of means but not their goals, and too broad, because 
Amendment jurisprudence in that it assumes that people are ordinarily the best judges of their own interests and of the methods necessary for satisfying those interests. Normally, the availability of greater information can only benefit economically rational individuals - the more information individuals have, the more knowledgeably they can define their ends, calculate their means, and plan their actions. ${ }^{17}$ Given the similarity between the views of human nature underlying economic theory and the First Amendment, it should not be too surprising that economics can illuminate First Amendment doctrine.

\section{INFORMATION AS A PUBLIC GOOD}

Over the past twenty years, economists have become increasingly interested in the economics of information. Their most basic finding, subject to some qualifications, is that markets are likely to produce too little information ${ }^{18}$ because information, like clean air or national defense, has many of the attributes of a public good. That is, the benefits of information cannot be restricted to direct purchasers but inevitably spread to larger groups. ${ }^{19}$ The production of information

it assumes perfect rationality about the choice of means. See Richard H. Pildes \& Elizabeth S. Anderson, Slinging Arrows at Democracy: Social Choice Theory, Value Pluralism, and Democratic Politics, 90 CoLUM. L. REV. $2121,2143-48$ ( 1990$)$ (critiquing the conception of rationality that underlies both conventional economic theory and social choice theory).

17 A rational individual would simply disregard any information that did not lead to improved decisionmaking. Hence, in a rational choice model, the availability of information can have socially undesirable consequences only if some collective action problem converts individually optimal conduct into a suboptimal social outcome. Such collective action problems and human beings' imperfect rationality may produce circumstances in which suppressing information would in fact increase welfare. One example is the prisoners' dilemma, in which each of two prisoners confesses because each is afraid that the other will confess and implicate him. By confessing, however, the prisoners make themselves worse off than they would have been if they both had remained silent. See ERIC RASMuSEn, Games AND InFormation 28-29 (1989). Each would be better off if he were unaware of the other's arrest and mistakenly thought the arrest unlikely. For a more general discussion of the advantages flowing from the structure of political institutions that limit political information, see Michael A. Fitts, Can Ignorance Be Bliss? Imperfect Information as a Positive Influence in Political Institutions, $88 \mathrm{MICH}$. L. REv. 917, 939-66 (1990). Nevertheless, the First Amendment clearly rests on the premise that such circumstances are exceptional.

${ }^{18}$ See Anthony T. Kronman, Mistake, Disclosure, Information, and the Law of Contracts, 7 J. LEGAL STUD. I, 17 n.46 ( 1978 ) (discussing the relationship between property rights in information and the level of information produced); Ejan MacKaay, Economic Incentives in Markets for Information and Innovation, I3 HARV. J.L. \& PUB. PoL'Y 867, 890-96 (I990) (discussing the non-deteriorating, non-rival, and non-exclusive properties of information); Posner, supra note 10, at 19-20 (discussing the effects of information's communal property attributes on production). This point is also discussed by Cass. See Cass, supra note I, at I366 n.20I (citing sources).

19 Why should I pay for the production of information or clean air? Once these goods have been produced, I can get either one "on the cheap," and if they are not being produced, my own financial contribution is not going to have much effect on the supply. 
often produces positive externalities - that is, benefits to third parties. ${ }^{20}$ Because the producer does not consider these benefits in his production decision, less information is produced than is socially optimal. There are people who, if they had to, would be willing to pay for the benefits of additional information, but that additional information is not produced because the market is unable to translate those individuals' preferences into an incentive for the producer. ${ }^{21}$ Market demand reflects only benefits to purchasers, not benefits received by free riders. According to this analysis, if the government intervenes in the market at all, it should subsidize speech rather than limit it. Legal restrictions on information only further reduce a naturally inadequate supply of information. ${ }^{22}$

Virtually any activity can produce third-party benefits of some kind under the appropriate circumstances. Third-party benefits are least likely to occur in the case of discrete physical goods. Only one person can consume a given meal or drive a certain car at a particular time. Information, however, is perhaps uniquely reproducible. The same idea or the same data can be understood simultaneously by an indefinite number of individuals at relatively little marginal cost. Once information is produced, it can be made available to a broader audience in several ways - through physical reproduction, through paraphrasing, through information-sharing services such as libraries or press reports, and sometimes merely through observing the subsequent behavior of original audience members. These and other phenomena allow many individuals to consume the same item of information without compensating the original producer.

${ }^{20}$ I use the phrase "third-party benefits" to refer to benefits that can be derived directly from the informational content of speech and not to benefits that arise in response to speech. For example, circulating information to additional readers who borrow books from the library would be classified as a third-party benefit, but feminist critiques of pornography that arise in response to pornography would not.

21 In a recent article on the foundations of the First Amendment, Professor David Strauss questions whether it is possible, without detailed information about a person's concrete desires, to determine what information that person would "want in circulation." David A. Strauss, Perstasion, Autonomy, and Freedom of Expression, 9I Colum. L. Rev. 334, 370 (I991). Public choice theory suggests that, even without knowing more about the person, we can still conclude that she probably would want more information than the market or the legislature will provide.

22 In other words, legal restrictions on the production of information shift the supply curve up and cause a reduction in the quantity of information produced. For a graphic depiction, see Posner, supra note 10, at $2 \mathrm{I}$. For example, tort law must be adjusted to avoid unduly burdening the production of information. Normally, the tort system seeks to make enterprises liable for all the harms they cause and thus forces them to internalize the social costs of their operations. See Richard A. Posner, EConomic Analysis of LaW I48 (3d ed. I986). Requiring producers to internalize costs fully, however, will not lead to a socially optimal level of information production because producers cannot also internalize all the benefits of their enterprise. Hence, information activities should not be subject to full tort liability. I discuss this point further below. See infra pp. 568-69. 
Two more points about this argument deserve mention. First, the argument does not turn on the absolute value of speech compared with other activities but rather on the disparity between the private and social value, which is greater for speech than for typical consumer goods. Thus, it does not matter whether speech (or some category of speech) is more or less important to individuals or to society than some other consumer good, such as food. What is important is that a much greater share of the value of the food flows to the initial purchaser, and less flows to other members of society. Second, some speech may consist of misinformation, and its dissemination throughout socie ‘y may be a public "bad" rather than a public good. But if individuais are rational, they will usually screen out false information or refuse to rely at all on a communication if they cannot assess its reliability. This screening is by no means a foolproof process, and in some instances government intervention may be warranted to prevent the dissemination of false information. Nevertheless, the presumption should be that the free dissemination of information generally makes individuals more knowledgeable and improves their welfare.

Just as the market will underproduce information, the political system is likely to overregulate information. In general, consumers of information, like all large, diffuse groups of individuals with small. personal stakes, face serious organizational problems in lobbying and other political activities. Such collective action problems are due in part to the powerful incentive that individual members of such groups have to free ride. ${ }^{23}$ When the product in question is information, this effect is exacerbated because the benefits of improved information are so diffuse. Hence, although consumers of other products are often ineffective as a political force, consumers of information are even more likely to be dismal failures in preventing government from limiting information production.

In the context of nonpublic goods, producers may organize consumer protests or otherwise act as proxies for consumer interests because the producers' sales directly reflect the value of the product to consumers. Consider, for example, a government effort to regulate a new prescription drug. Consumers' willingness to purchase the drug translates directly into a financial stake for the producers (the drug companies) and the distributors (doctors and pharmacists). ${ }^{24}$ Because

23 We owe this insight to the economist Mancur Olson. See FARBER \& FrICKEY, supra note 7, at 23; Mancur Olson, The logic of Collective Action: Public Goods and the THEORY OF GROUPS I63-64 (1971). If Olson's theory is correct, we would expect to find the political process dominated by small groups of individuals seeking benefits for themselves what public choice theorists call "rent-seeking" special interest groups. See OLson, supra, at I64.

24 Similarly, insurance companies may represent the consumers' interest in making products safer. See, e.g., Motor Vehicle Mfrs. Ass'n v. State Farm Mut. Auto. Ins. Co., 463 U.S. 29, 46 ( 1983 ) (upholding insurance companies' challenge to the federal government's rescission of an automobile safety regulation). 
sales reflect most of the social benefits of the consumer good in this case, lobbying by producers can act as a partial proxy for lobbying by consumers. ${ }^{25}$ In the context of public goods such as information, however, the total social benefit of the good is not reflected in direct consumer sales. Payments to information producers, such as book publishers, reflect only the benefits received by direct purchasers and do not include the full benefit ultimately enjoyed by the rest of society from receiving the information indirectly. Because sales of information do not fully reflect the ultimate social benefit of information production, the producers' financial stake - and thus the intensity of industry lobbying on behalf of consumers - does not reflect the full social value of the information. Consequently, media lobbying efforts are a less effective proxy for consumer interests than are the efforts of producers in other industries. These barriers to lobbying by producers and consumers of information suggest that, to whatever extent the government may or may not tend to overregulate other behavior, it will be more likely to overregulate speech. Like other widely dispersed public benefits, information is likely not only to be underproduced in the private market, but also to be insufficiently protected by the political system. ${ }^{26}$ It is precisely this tendency to overregulate speech activities that requires constitutional protection for speech. ${ }^{27}$

25 The consumers' interests will be opposed to the producers' interests, however, if the producers seek anticompetitive legislation. If so, consumers themselves will have to oppose the legislation.

26 What about misinformation? False statements also will have spillover effects as they spread to nonpurchasers. If false statements were as prevalent and as believable as true statements, the net social value of speech could be zero - the "public bad" might cancel out the public good. But rational individuals should not be equally willing to accept true and false statements; rather, because they should ignore any statement unless they have a basis for assessing its reliability. "It is a fair generalization that no rational person ever wants to act on the basis of a false statement of fact." Strauss, supra note 21 , at 366 . Consequently, individuals should screen out more false statements than true ones and hence should be more likely to accept true statements. This is, of course, a variant of the basic "marketplace of ideas" concept, with the twist that the market should simply ignore any communications that cannot be screened for reliability.

${ }^{27}$ In a recent article, Professor Fred McChesney argues that the affected interest groups are likely to oppose restrictions on noncommercial speech. See Fred S. McChesney, A Positive Regulatory Theory of the First Amendment, 20 CoNN. L. REv. 355, 367-69 (1988). MICChesney's argument is flawed by his inconsistent definitions of the affected "industries." For example, Michesney says that a majority in the pharmaceutical industry prefers a flexible treatment of commercial speech. See id. at $366_{3}$. In contrast, he claims that a majority in the "industry" of politics favors a strict rule against restriction because, at any given time, most potential officeholders are not incumbents. See id. at 366 . McChesney does not explain why in the one case we should consider those persons interested in gaining political office as part of the interest group, whereas in the other we should not consider those persons interested in entering the drug industry. Restrictions on commercial speech act as a barrier to entry; if one considered all potential business owners or stockholders as part of the affected interest group - as McChesney does with regard to the political interest group - one would expect to find a majority of the interest group favoring unrestricted commercial speech.

Similarly, McChesney defines the industry relevant to other forms of censorship as consisting 
On a hasty reading, this argument might seem to suggest that speech produces only benefits and therefore should be virtually immune from regulation. The argument is actually more limited. Like any other activity, speech may impose costs on third parties, and when these externalities exceed the total social value of the speech, regulation may be in order. But regulation of speech should be viewed with special caution because information is already produced at a suboptimal level and legislatures are particularly prone to overregulate speech. Consequently, government regulation of speech should be more restrained than regulation of other activities.

As I explain in Parts III and IV, the public good characteristics of information explain much of current First Amendment doctrine. Even when the theory gives some general support for current doctrine, however, it does not provide specific guidance about where to draw lines. For example, the theory supports the judicial concern over chilling effects reflected in the doctrines of vagueness and overbreadth, ${ }^{28}$ but it provides little guidance about just how much vagueness or overbreadth should be permitted. ${ }^{29}$ Furthermore, even features of First Amendment doctrine that can be explained by public choice theory are often bolstered by noneconomic justifications as well. For example, vagueness and overbreadth doctrines also involve concerns about discriminatory enforcement against unpopular groups. ${ }^{30}$ Nevertheless, the economic theory is remarkably illuminating.

\section{Defining Protected Speech}

Everyone seems to agree that political speech lies at the core of the First Amendment's protection. At the periphery are forms of speech such as pornography and commercial advertising. As it turns out, core speech most strongly exhibits the qualities of a public good

of those who generate ideas. See id. at 368-69. Perhaps a majority of those individuals would disfavor restrictions on speech. It seems odd, however, to define the industry as the work force rather than the firms that employ the workers. Those responsible for the dissemination of ideas, such as the mass media, journals, and magazines, can reap some benefits from restricting competition. Surely Time would gain from eliminating Newsweek and U.S. News and World Report. There is no reason to think that demand for periodicals is so elastic that supracompetitive returns from restricting output would be impossible, as McChesney implies. See id. at 368.

${ }^{28}$ See infra pp. 569-70.

29 Given sufficient empirical data about matters such as the elasticity of supply of information, the theory could provide more detailed guidance. In reality, however, such quantitative data is not available and is unlikely ever to be available, and thus the line-drawing must rely heavily on informed common sense. Nevertheless, formal modeling of some First Amendment problems may sometimes be illuminating.

30 See TRIBE, supra note I, $\$$ I2-I, at ro33. 
and therefore most needs protection, while the forms of speech at the periphery are only weak public goods.

Political speech might well be considered a "double" public good. Information contained in political speech is one public good, and political participation, which is often guided by such information, is a second public good. Consider, for example, the supply of information about foreign affairs. To the extent that voters seek such information, they can often obtain it secondhand without paying the original producer. The free rider problem is exacerbated in this context because voters also have an incentive to free ride on the activities of other political participants. Because my vote probably will not change the election results, I have little incentive to seek relevant information. Even if the information were only privately available, I would have little incentive to pay for it. Instead, I might as well sit back and let other people participate in politics. I will obtain whatever benefits exist from a good foreign policy regardless of whether I participate. ${ }^{31}$ The result is predictably straightforward: although information in general is likely to be underproduced, political information is even more likely to be underproduced, and underproduced to a greater extent. Furthermore, because information producers will capture only a tiny share of the ultimate benefits of their product in the form of better government, their lobbying activities against censorship similarly will be underfinanced. Therefore, the public good argument for protecting speech applies with particular force to political speech. ${ }^{32}$

This argument for protecting political speech does not assume any special malice or even insensitivity on the part of government officials toward disclosure of adverse political information. Although government officials may have conflicts of interest concerning the regulation of political speech, ${ }^{33}$ such conflicts are insufficient by themselves to justify especially stringent protection of political speech. We do not necessarily disallow legislation whenever politicians have a conflict of interest, such as that in cases involving political gerrymandering ${ }^{34}$ and

31 This insight can be traced back to Mancur Olson. See OLsoN, supra note 23, at 13-16.

32 Posner uses this argument, among athers, to justify protecting political speech. See Posner, supra note Io, at 23-24.

33 See Cass, supra note $I$, at $1354-56$ (discussing politicians' temptation to abuse their "agency" relationship with the electorate by restricting speech that threatens their own selfinterest); see also Ronald A. Cass, The Perils of Positive Thinking: Constitutional Interpretation and Negative First Amendment Theory, 34 UCLA L. REV. 1405, 1449 (1987) (arguing that the Framers viewed the First Amendment, at least in part, as a check on speech regulation by selfinterested officials). But see Posner, supra note to, at $\mathbf{1} 3$ (discounting "the argument that censors will have a conflict of interest in dealing with speech critical of the government that employs them").

34 In fact, in the political gerrymandering setting, the inherent conflicts of interest have prompted some justices to counsel judicial restraint rather than judicial intervention. See Davis 
public funding for campaign expenses. ${ }^{35}$ Thus, at the very least we need further argument to connect the harm (a political conflict of interest) with the remedy (constitutional protection of speech).

Moreover, the conflict of interest is not always as strong as it may appear. Political challengers have strong incentives to oppose restrictions on information. Even for incumbents, suppressing adverse information may not be desirable. Whether suppressing information is a good strategy depends on the expectations people have in the absence of information. For example, if people think most incumbents are crooks, it is to the collective advantage of incumbents to suppress information about corruption only if the situation is even worse than people suspect. ${ }^{36}$ This is an application of what has been called the "No News Is Bad News" principle in game theory. ${ }^{37}$ For this reason, incumbents will often be divided about the desirability of suppressing information.

In addition, politicians' incentive to suppress adverse information can be viewed as a special case of their general incentive to favor politically organized special interests at the expense of the unorganized public. Politicians always have at least a potential conflict of interest between their own desire to be reelected and their desire to serve the public, at least to the extent that the politician's honest perception of the public interest does not agree with the latest poll results. Politicians should not be understood as a unique force for suppressing information, but rather as simply another special interest that sometimes wishes to suppress information. Normally, special interests are countered by various other forces, but we have already seen that information producers have an insufficient motive to lobby against restrictions on information and that this motive is especially weak when political speech is concerned because of the "double" public good problem. Additionally, of course, politicians do have advantages that assist them in obtaining legislation favorable to their interests: they have inside political knowledge and an organizational structure designed for taking political action. The likely result of these advantages is that too much political speech will be suppressed.

v. Bandemer, 478 U.S. Iog, I43-44 (1986) (Burger, C.J., concurring) (arguing that gerrymandering cases turn on political questions properly left to elected representatives); $i d$. at 144 (O'Connor, J., concurring) (same).

35 In deciding First Amendment challenges to campaign contribution statutes, the Supreme Court often has failed even to consider legislators' potential conflicts of interest. See, e.g., Austin v. Michigan Chamber of Commerce, i IO S. Ct. I39r, I402 (r990) (upholding a state law prohibiting curporations from using corporate treasury funds for independent expenditures in state candida.e elections); Buckley v. Valeo, 424 U.S. I, 30-35, 85-86 (1976) (per curiam) (upholding campaign contribution limitations and the public financing of presidential election campaigns despite the potential in such measures for discriminating against electoral challengers).

${ }^{36}$ If, for example, the public thinks that most politicians are crooks, but only $40 \%$ of them actually are, the other $60 \%$ have a collective incentive to establish a credible system of information about crooked politicians.

37 See RASMUSEN, supra note 17 , at 162. 
On the other end of the spectrum, consider pornography. True pornography seems to have little or no informational content; 38 it is more like an ordinary consumer good. ${ }^{39}$ There are few facts or ideas to be spread beyond the initial purchaser and little, if any, potential benefit to third parties. The erotic content ensures a high demand by direct purchasers that far outweighs any incidental benefit to third parties. Thus, there is no reason to expect pornography to be underproduced in the sense that some people would be willing to consume more pornography than an unregulated market would provide. Hence, pornography is no more likely to be overregulated than the typical consumer good and should not be treated as a form of "speech."40 The same analysis applies to nude barroom dancing of the kind involved in Barnes v. Glen Theatre, Inc. ${ }^{41}$ Whatever benefits the naked dancers produce can be captured by the dancer in the form of increased tips (the asserted motivation for one of the plaintiffs in Barnes $^{42}$ ) or by the bar, if necessary, in the form of a cover charge. ${ }^{43}$

Commercial speech also closely resembles a private good. Most of the benefit of product advertising is captured by the producer itself in the form of increased sales. ${ }^{44}$ Consequently, we would not expect severe underproduction of commercial speech. ${ }^{45}$ Even casual exposure to the American media is enough to convince most people that advertising is already produced at an ample level. Nevertheless, advertising may have some broader benefits, notably the improved functioning of the market as a whole because consumers face lower information costs. ${ }^{46}$ Not surprisingly, the Supreme Court formerly

38 See Miller v. California, 413 U.S. 15, 24 (1973) (defining pornography as prurient, erotic material lacking any serious literary, artistic, political, or scientific value).

${ }^{39}$ One can argue that pornography conveys a message that degrades women. But this message is nol conveyed as a deliberate communication. Rather, it is transmitted by effecting an involuntary attitudinal change in those exposed to the materials. In this respect, pornography has less of a claim to consideration as a form of "speech" than symbolic speech, in which normally noninformational activities are deliberately used to communicate overt messages.

40 See Posner, supra note Io, at 22. Of course, some degree of constitutional protection may be necessary to prevent chilling other forms of sexually explicit but more valuable speech. For this reason, it is not surprising that cases such as Miller do attempt to provide some degree of protection for erotic materials. See Miller, $4{ }^{1} 3$ U.S. at 24.

41 III S. Ct. 2456 (I99I).

42 See id. at 2459.

43 The Bames Court did extend minimum First Amendment protection to nude dancing in bars. See id. at 2460. A noneconomic argument might be made for protecting this dancing as a form of self-expression. But from a purely economic perspective, it is hard to envision any public good aspect to this communication, unless one is prepared to view the possible increase in prostitution and drug trafficking in the vicinity as a positive externality.

${ }^{44}$ There is, of course, a benefit to the consumer who would otherwise have purchased the product but decides on the basis of the advertising not to buy the product because of improved information. This benefit is probably quite small, however, because the seller has an obvious interest in minimizing this effect.

45 See Cass, supra note $\mathrm{I}$, at $\mathrm{r} 334, \mathrm{r} 366$, I368-69; Posner, supra note ro, at 40.

46 See Cass, supra note $\mathrm{I}$, at $\mathrm{I}_{367-68}$. Cass argues that such information benefits consumers 
did not consider commercial speech to be protected at all ${ }^{47}$ and now gives it less protection than other forms of speech. 48 Although commentators have subjected the Court's rationale to scathing criticism, ${ }^{49}$ economic analysis provides solid support for the Court's reluctance to provide full protection to commercial speech.

Public choice theory also demonstrates that commercial speech can be distinguished from two seemingly similar forms of speech: product information distributed by a third party and charitable solicitation. Product information distributed by a third party produces benefits that are captured by persons other than the speaker. The speaker, therefore, has an inadequate motivation to produce this information. Consider Consumer Reports. The buyers of the journal can make more informed product decisions, but nonbuyers also benefit by getting the journal at the library, ${ }^{50}$ hearing about its findings by word-ofmouth, or even less directly by observing the purchasing behavior of Consumer Reports readers. Because the journal cannot capture any of these benefits, information of this kind will be produced at a socially suboptima' level. Thus, speech about commercial subjects by third parties should be fully protected and should not be viewed as mere commercial speech. ${ }^{51}$ The Court was correct to classify Consumer Reports as part of the "media" rather than as a commercial speaker. ${ }^{52}$

by channeling them to products that better fit their preferences. See id. at r368 n.2 Ir; see also Fred S. McChesney, Commercial Speech in the Professions: The Supreme Court's Unanswered Questions and Questionable Answers, 134 U. PA. L. REv. 45, 78-81 (1985) (arguing that if advertising is banned, vendors of professional services will spend more money on less efficient methods of self-promotion and will cause prices for their services to increase).

${ }^{47} \mathrm{See}$ Valentine v. Chrestensen, 316 U.S. 52, 54 (1942).

48 See, e.g., Posadas de Puerto Rico Assocs. v. Tourism Co., 478 U.S. 328, 345-46 (I986); Central Hudson Gas \& Elec. Corp. v. Public Serv. Comm'n, 447 U.S. 557, 566 (I 980 ); Virginia State Bd. of Pharmacy v. Virginia Citizens Consumer Council, Inc., 425 U.S. $748,770-73$ (I976).

49 See Alex Kozinski \& Stuart Banner, Who's Afraid of Commercial Speech?, 76 VA. L. REv. 627 (I99o).

so Note, however, that the publishers of Consumer Reports might follow a common practice among scholarly journals and charge the library a higher fee to capture some of this public benefit. As with other forms of price discrimination, enforcement and prevention of arbitrage can be problems. For instance, libraries may enter subscriptions under the names of individual librarians to avoid paying library rates.

51 It is incorrect to contend that potentially misleading commercial speech should receive the same level of protection as similar product information from independent sources, as Professor Redish implicitly argues in a recent article. See Martin H. Redish, Product Health Clainss and the First Amendment: Scientific Expression and the Twilight Zone of Commercial Speech, 43 VAND. L. REv. I433, I444-45 (I990). Twelve years ago I argued for full protection of truthful commercial speech on similar grounds, see Daniel A. Farber, Commercial Speech and First Amendment Theory, 74 Nw. U. L. REv. 372, 399 (1979), but I now regard that argument as unfounded.

52 See Bose Corp. v. Consumers Union of the United States, Inc., 466 U.S. 485,492 n.8 (1984). 
Charitable solicitation also seems superficially similar to commercial speech, yet it has received full First Amendment protection. ${ }^{53}$ In fact, charitable solicitation differs from commercial speech in that it often involves the transmittal of information about the societal problems that the charity proposes to address as well as the charity's own perspective on the problem. ${ }^{54}$ Third parties will tend to free ride on a charity's dissemination of this information through solicitation. For instance, if the charity publicizes the problems of the homeless, the information becomes available to noncontributors. Moreover, charitable activity itself is a public good. ${ }^{55}$ The charity benefits from increased contributions, but so do all the free riders who let other people "do their giving." Consequently, the charity's activities, and hence the solicitations to fund those activities, confer benefits on third parties. This positive externality ensures that solicitation takes place at a suboptimal level. ${ }^{56}$ In contrast, there is no evidence of an unmet consumer desire for more commercial speech, such as advertising.

The question immediately arises: how does protected speech differ from other public goods, such as clean air or national defense, that are not protected as constitutional rights? Two distinctions seem to exist. First, protecting an activity from governmental burdens has practical importance only if the "natural" (that is, unregulated) level of activity is fairly high. Information is underproduced by the market, but the natural level produced is relatively high in comparison with national defense or clean air. Even without governmental burdens, the private sector simply will not voluntarily produce much pollution control or national security. Second, judicial efforts to promote the production of these other public goods would face severe administrative difficulties. Courts can promote free speech simply by declaring laws invalid. In contrast, doing anything about national defense or the environment requires complex, expensive, and expert action that

${ }^{53}$ See Village of Schaumburg v. Citizens for a Better Env't, 444 U.S. 620, 628-32 (1980).

${ }^{54} \mathrm{See}$ id. at 632 .

55 See POSNER, supra note 22 , at $438-41$. Posner's argument is twofold. As a preliminary matter, he pasits that the existence of poverty imposes a net cost on society in the form of increased crime and, more significantly, in the form of disutility imposed on affluent altruists. Charitable giving provides a cognizable benefit by eliminating these costs. See id. at 439 . The second prong of Posner's argument is that alleviation of poverty is a public good because nongivers may free ride on the contributions of givers. See id. at 440 . Thus, if I wish to see the homeless fed, I can free ride on your charitable contribution, which will feed the homeless at no expense to me. Posner's analysis provides a basic economic argument for government welfare programs.

56 Thus, like political speech, charitable solicitation is a "double" public good in that both the information that drives charitable giving and the giving itself are underproduced because third parties can benefit from the actions of others without expending any effort themselves. Affluent altruists benefit from the charitable donation of other altruists and therefore have an incentive to free ride. 
courts are ill equipped to provide. These other public goods must be provided through other strategies.

Even regarding communication, the First Amendment is far from being the only strategy used to combat underproduction. Within the Constitution itself, the Copyright Clause $^{57}$ authorizes the creation of private property rights in expression and thereby helps to mitigate the public good problem. ${ }^{58}$ Direct subsidies to information production, in the form of research grants and governmental support for universities, also help counter the private sector's inability to produce a socially optimal level of information.

In fact, public choice theory suggests that the conventional approach to the First Amendment has prompted an excessive focus on avoiding restrictions on speech at the expense of the equally important goal of actively promoting speech. Judicial enforcement of a governmental duty to promote speech is probably infeasible and unwise, because it would suggest an enforceable constitutional duty to provide all public goods. ${ }^{59}$ Nevertheless, recognition of a nonenforceable duty to promote informational activities might have important practical consequences by providing symbolic support for governmental subsidies. Enforcing the First Amendment prohibitions on restrictions of speech is only one of the strategies for producing more information, but it is a highly important one.

\section{Doctrinal Protections for SpeEch}

Many First Amendment doctrines reflect the fear that certain laws overdeter speech and thus lead to a suboptimal amount of total information disseminated in society. For example, cases such as New York Times Co. v. Sullivan ${ }^{60}$ provide extraordinary protection for enterprises that harm others through their communications. ${ }^{61}$ As the

57 U.S. Const. art. I, $\S 8$, cl. 8.

${ }^{58}$ In his treatise on freedom of speech, Professor Nimmer seeks to balance the conflicting ideals underlying the Copyright Clause and the First Amendment. See Melville B. Nimmer, Nimmer on Freedom of Speech: A Treatise on the Theory of the First Amendment $\S 2.05[\mathrm{C}][2]$, at $2-6 \mathrm{I}$ to $2-84$ ( 1984$)$. Nimmer recognizes that the copyright laws in some degree abridge freedom of speech and that an absolutist reading of the First Amendment would obliterate the Copyright Clause. See id. at $\S 2.05[\mathrm{C}][2]$, at 2-58. Although Nimmer is correct that, on a certain level, the Copyright Clause and the First Amendment conflict, the economic perspective on free speech demonstrates that their basic purpose is the same - encouraging the optimal production of socially valued information.

59 Judicial enforcement of a duty to promote speech would face many of the same obstacles as a judicially enforceable right to clean air or a strong national defense.

${ }^{60} 376$ U.S. 254 (1964).

61 In New York Times, the Supreme Court held that a public official cannot recover damages for a defamatory falsehood relating to his official conduct unless he proves that the statement was made with knowledge of its falsity or with reckless disregard for the truth. See id. at 27980. In Curtis Publishing Co. v. Butts, 388 U.S. I30 (I967), a majority of the Justices agreed 
Court in New York Times recognized, if newspapers were liable for all inaccuracies, they would strike the wrong balance between the costs of inaccurate information and the benefits of producing additional accurate information. ${ }^{62}$

For example, suppose an editor knows that a story is sixty percent likely to be correct and that publishing the story will increase the paper's profits by $\$ 100,000$. If the story is true, it will produce a net social benefit of $\$ I$ million, but if it is false, the paper will have to pay defamation damages of $\$ 500,000$. If the decision is based on the total social benefits, the paper should publish the story. ${ }^{63}$ Yet if the paper considers only its own economic incentives, it will refuse to publish because it faces an expected loss of $\$ 100,000.64$ To prevent overdeterrence, we must provide the paper considerable protection against liability. ${ }^{65}$

Just as tort damages may overdeter newspapers, litigation costs or legal uncertainty may overdeter other speakers. A legal rule that deters harmful speech may impose greater costs than benefits if it also

with Chief Justice Warren's reasoning extending this rule to include defamatory statements concerning public figures. See id. at $1_{162-65}$ (Warren, C.J., concurring in the result); $i d$. at 170 (opinion of Black, J.); id. at 172 (opinion of Brennan, J.).

${ }^{62}$ See NInMER, supra note $58, \$ 2.05[\mathrm{C}][2]$, at $2-44$ (arguing that the highly protective balance set forth in New York Times was justified because society as a whole has an interest in the dissemination of information). The public figure rule also contributes to an appropriate balance in that the cost of a defamatory statement is less when made against a public figure, who, by virtue of her position, can more easily clear her good name. See Gertz v. Robert Welch, Inc., 418 U.S. 323, 344 (1974); cf. Whitney v. California, 274 U.S. 357, 377 (1927) (Brandeis, J., concurring) (stating that "the remedy to be applied is more speech, not enforced silence"), overniled by Brandenburg v. Ohio, 395 U.S. 444,449 ( 1969 ).

63 If only true stories produce social benefits, the expected net social benefits of publication are $60 \%$ of $\$ 1$ million, or $\$ 600,000$. If damages are fully compensatory, the costs are $40 \%$ of $\$ 500,000$, or $\$ 200,000$. This calculation assumes a zero social cost for truthful information that is injurious to reputation, because the cost to the defamed individual should be offset by the value of the information to others. Alternatively, the sil million in net social benefits could be considered net of the harm to the defamed individual. The expected net social benefit of publication is thus $\$ 400,000$. Obviously, this is a highly simplified cost-benefit analysis.

64 The $\$ 100,000$ loss is arrived at by subtracting the expected costs of defamation damages, $40 \%$ of $\$ 500,000$, or $\$ 200,000$, from the paper's increased profits of $\$ 100,000$. This calculation assumes that the jury will be perfectly accurate in determining falsehood, but even under that optimistic assumption, defamation law overdeters.

${ }^{65}$ This analysis suggests that tort liability for defamation should be limited but does not establish the exact extent and form of the limitations. As a practical matter, the economic information that would be required for a cost-benefit analysis of liability limitations is not usually available, and thus an informal balancing approach must be used to establish those limitations. See Richard A. Epstein, Was New York Times v. Sullivan Wrong?, 53 U. CHI. L. REV. $782, S_{17-1} \&$ (Ig86). As Epstein points out, the limitation on liability chosen by the Court in New York Times is not necessarily optimal. See id.

Note that this argument assumes that the tort liability is directly tied only to the level of information production. Tort liability for unrelated activities is a different matter. Such liability affects the newspaper's profit level but not the marginal cost of information production. 
deters the generation of beneficial information. The inefficiency involved in overdeterrence helps to explain the deep concern about "chilling effects" found in First Amendment jurisprudence. ${ }^{66}$ Doctrinally, this concern is most clearly expressed in the rules against vagueness and overbreadth. ${ }^{67}$ These rules reflect the Court's willingness to sacrifice the deterrence of harmful conduct to prevent the chilling of constitutionally protected speech. Speech is more likely to be chilled than other activities because most of its benefits are not captured by the speaker. ${ }^{68}$ As a result, a person may be unwilling to take even a small risk of prosecution under an overbroad or vague statute. The overbreadth doctrine, however, does not apply to commercial speech, ${ }^{69}$ the benefit of which is substantially internalized by the speaker. ${ }^{70}$

The characteristics of information as a public good also explain why even content-neutral regulations receive judicial scrutiny. ${ }^{71}$ When only the interests of the speaker and those harmed by the speech are considered, it may seem reasonable to restrict methods of speech in order to reduce externalities. ${ }^{72}$ The legislative process will reflect

${ }^{66}$ See NAACP v. Button, 37Y U.S. 4I5, 433 (I963); see also Posner, supra note ro, at 47 (noting the risk of overdeterrence that arises because speakers do not take into account the full social benefits of their speech).

${ }^{67}$ Under the overbreadth doctrine, a statute is unconstitutional if it substantially burdens or prohibits activities covered by the First Amendment, even though its purpose and principal function is to regulate unprotected conduct. See 3 RoNAld D. Rotunda, JoHn E. NowaK \& J. Nelson Young, Treatise on Constitutional Law $\$ 20.8$, at 24 (1986).

The vagueness doctrine rests on the same "chilling" rationale as the overbreadth doctrine. See id. $\$ 20.9$, at 34. Essentially, a vague law is one whose prohibitory scope is unclear. See id. $\$ 20.9$, at $34-35$. A vague law will be held to be unconstitutional even if it may have a number of constitutional applications. See id. $\S 20.9$, at 36 .

${ }^{6 \delta} \mathrm{Cf}$. Posner, supra note Io, at 47 ("A small expected private cost [for example, the expectancy of prosecution under an overbroad or vague statute] may exceed a small expected private benefit - which may, however, be a substantial expected social benefit."). If one takes the economic analysis one step further, one sees that the danger of the chilling effect is not that it inhibits speech. After all, from an economic perspective speech should be inhibited when its social costs outweigh its social benefits. See supra note to. Rather, the danger of the chilling effect is that it causes speech to be produced at a suboptimal level.

${ }^{69}$ See Bates v. State Bar, 433 U.S. 350, 380-81 (1977); Virginia State Bd. of Pharmacy v. Virginia Citizens Consumer Council, Inc., 425 U.S. 748, 77 I n.24 (1976).

${ }_{70}$ See Posner, supra note Io, at 47 . The Court has explicitly linked its refusal to apply these doctrines to the commercial speaker's financial incentives, which counter any chilling effect. See Bates, 433 U.S. at 380-8I; Virginia State Bd. of Pharmacy, 425 U.S. at 771 n.24.

${ }^{71}$ In Ward v. Rock Against Racism, 49I U.S. 78I (1989), the Court held that time, place, and manner regulations are permitted under the First Amendment as long as they are "narrowly tailored to serve the government's legitimate, content-neutral interests." Id. at 798 . The narrowly tailored requirement does not mean that the government must pursue the least restrictive means of fulfilling its objective. Rather, the requirement is satisfied if the regulation helps to achieve "a substantial government interest that would be achieved less effectively absent the regulation." Id. at 799 (quoting United States v. Albertini, 472 U.S. 675, 689 (1985)).

i2 See Posner, supra note Io, at 30. 
the influence of speakers (perhaps) and the influence of those harmed by the speech, but not the interests of indirect beneficiaries of the speech. ${ }^{73}$ Thus, the legislature will again have an incentive to overregulate, even when restrictions are content neutral.

Decisions that invalidate content-neutral rules can also be viewed as forced subsidies of speech by onlookers, who must contend with increased traffic, littering, noise, or other costs. ${ }^{74}$ Because information is underproduced, a subsidy of this type is desirable. ${ }^{75}$ As long as limiting content-neutral restrictions on speech spreads costs widely and thinly, it remains a reasonably equitable way of providing a subsidy. Captive audience rules have a similar effect. Forcing some people to put up with speech they would rather avoid effectively forces them to subsidize the speech. As long as the effects are not too intense and are not focused on too small a group, however, the subsidy is justified. ${ }^{76}$

This analysis helps illuminate the recent debate about hate speech. ${ }^{77}$ Many situations involving hate speech also involve captive

${ }^{73} \mathrm{Cf}$. Cass, supra note $\mathrm{I}$, at $\mathrm{I} 333$ (discussing Posner's claim that special rules protecting speech are required to maximize social welfare because information is a public good).

Judge Posner explains time, place, and manner rules as the equivalent of taxes. See Posner, supra note Io, at I6. As Posner points out, content-neutral regulations of conduct should be treated more leniently than content-based restrictions because the former impose costs on individuals other than receivers of information. These persons will in turn put political pressure on the government and thus ensure a more accurate consideration of the costs and benefits of a particular content-neutral regulation. $S e e$ id. at $17-18$.

${ }^{74}$ An extreme example showing the costs imposed by speech is the well-known Nazi parade through Skokie, Illinois. The parade imposed costs on the Jewish residents of Skokie, who understandably found the demonstration extremely offensive. See Posner, supra note 1o, at $30-$ 3r. Posner considers the possibility that allowing the parade may have been incorrect because the costs of the expressive activity were so high and the benefits were likely to be low. See id. Arguably, such speech - like the use of "fighting words" - is a very weak public good because most of the benefit is recaptured by the speakers in the form of pleasure derived from the psychic torment inflicted on the audience. See id. (arguing that the Nazi parade was not designed to disseminate meaningful ideas but rather was intended to evoke a negative emotional response from onlookers). Whether a sufficiently clear regulation could be drafted to avoid overbreadth and vagueness challenges is another matter.

75 See supra pp. 558-59.

${ }^{76}$ In Cohen v. California, 403 U.S. I5 (I971), the Court recognized that, although the government may properly regulate speech to protect individuals in the privacy of their own homes, it has limited power to protect individuals in public places. See id. at $2 \mathrm{r}-22$. As the Court observed, unwilling audiences who were briefly exposed to Cohen's expressive activity (a jacket bearing the words "Fuck the Draft") could avoid the expression merely by averting their eyes. See id. at 16,21 . Laurence Tribe has suggested that the captive audience theory might be accepted if the expressive activity is of such an intensity "that the offended really have no time to avoid the unwanted impact." TRIBE, supra note I, \$ I2-I9, at 953.

77 There has been a dramatic increase in scholarly interest in hate speech recently. See, e.s., J. M. Balkin, Some Realism About Pluralism: Legal Realist Approaches to the First Amendment, I990 DUKE L.J. 375; Katherine T. Bartlett \& Sean O'Barr, The Chilly Climate on College Campuses: An Expansion of the "Hate Speech" Debate, I9go Duxe L.J. 574; Charles R. 
audiences, such as when women or members of racial minorities are involuntarily exposed to abusive epithets. ${ }^{78}$ Normally, we require individuals to tolerate such exposure as a way of subsidizing speech. Even if the cost is spread thinly, however, hate speech gives rise to an additional distributional concern. The psychic cost of hate speech is not randomly distributed through society but instead falls along racial or gender lines. ${ }^{79}$ We have a strong normative belief that social costs should fall evenly on different racial and gender groups. Although we do not demand equality at all costs, our belief in a more equitable distribution of social costs does justify taking captive audience costs more seriously in the context of hate speech and perhaps justifies somewhat greater regulation of such speech. ${ }^{80}$

A more difficult situation is presented when the legislature chooses to offer a selective subsidy for information by discriminating among related types of speech. Such a funding restriction may be attacked under the unconstitutional conditions doctrine, a notorious conceptual quagmire. I do not purport to resolve the difficult issues posed by that doctrine, but it may be relevant to point out some implications of the public good theory of free speech. As explained above, Congress will typically choose suboptimal funding levels; larger rather than smaller subsidies for speech would be desirable. If a court strikes down the speech restriction imposed by the discriminatory funding program and the program remains otherwise intact, the result will be a desirable increase in the availability of the subsidy. In contrast, if the legislature responds by eliminating the subsidy altogether, the result will be a lower level of information, unless private funding sources take up the slack. Thus, to decide whether striking down the restriction would increase social welfare a court would need to understand the legislative dynamics behind the subsidy. A court would need to determine whether the challenged provision is so crucial that the legislature would prefer to eliminate the program altogether rather than continue it without the condition and, if so, whether private funding would increase in response to the termination.

Lawrence III, If He Hollers Let Him Go: Regulating Racist Speech on Campus, 1990 Duke L.J. 43I; Nadine Strossen, Regulating Racist Speech on Campus: A Modest Proposal?, I9go DUKE L.J. 484.

${ }^{78} \mathrm{See}$ Balkin, supra note 77 , at $4^{\mathrm{r} 4-28}$ (discussing the captive audience problem).

79 Professor Balkin argues that when we subsidize racist speech by, for example, allowing access to public forums, we subsidize racism. See Balkin, supra note 77 , at 377. Professor Lawrence argues further that allowing racist or sexist speech to go unregulated actually hinders the flow of information by devaluing or oppressing speech that would otherwise be produced by women or persons of color. See Lawrence, supra note 77 , at 468 \& nn. 135-37.

80 Overbreadth and vagueness, however, remain serious concerns in the drafting of such regulations. Although chilling negative ideas about women or minorities may initially seem attractive, it risks the same side effects as the forms of viewpoint discrimination discussed below. See infra pp. 577-78; see also Strossen, supra note 77 , at $526-30$ (arguing that regulating hate speech on campus will chill serious and beneficial academic discourse). 
When the scope of a funding restriction is unclear, it should be given its minimum possible scope. In that way, speech will be restricted as little as possible. If the statute is ambiguous, there is no reason to believe that Congress prefers the broader restriction to the narrower restriction, nor is there any reason to think that Congress desires the broader restriction so strongly that it would prefer to have no program at all without it. Hence, a court has no reason to adopt the more restrictive (and less socially desirable) interpretation. ${ }^{81}$ If Congress rejects the narrower interpretation by amending the statute, the court must face more difficult questions. The court should then consider not only whether the broader restriction is defensible, but also whether rejecting it will torpedo the entire program and reduce the total availability of information.

Thus, in cases such as Rust v. Sullivan, ${ }^{82}$ in which a federal statute is ambiguous, the statute should not be construed to restrict the speech of subsidized entities. If supporters of the restrictive condition are unable to obtain a clear legislative statement in their favor, they probably also lack the votes to have a program repealed once the ambiguity is resolved against them. Thus, the Rust Court should not have upheld an administrative interpretation that virtually prohibited discussions of abortion by federally subsidized family planning clinics. ${ }^{83}$ A contrary decision would have increased the availability of information and thereby would have furthered a First Amendment goal. ${ }^{84}$ Indeed, subsequent Congressional action made it clear that Congress would have accepted a contrary Supreme Court ruling in

st A Supreme Court decision striking down a restriction has a significant symbolic and normative impact that will affect the political debate on whether Congress should "torpedo" the program. For example, if the Supreme Court strikes down content restrictions on art grants by the National Endowment for the Arts (NEA), it legitimizes the idea that the NEA is protected from the political, or even moral, sensibilities of senators.

82 Ii S. Ct. I759 (r991).

83 The Court upheld the regulation as a permissible exercise of agency discretion. See id. at 1767-69. Valid reasons exist for the established rule of deference to agency interpretations of statutes. See Chevron U.S.A., Inc. v. Natural Resources Defense Council, Inc., 467 U.S. $837,864-66(1984)$. These considerations are overborne, however, in the context presented in Rust. See The Supreme Court, Iggo Term - Leading Cases, Io5 HARv. L. Rev. 177, 397-99 (I9gI).

34 This analysis assumes, however, that the restriction on speech is not warranted. In the setting of Rust, for example, the assumption is that the fetus does not count as a potential recipient of an external cost if the abortion is performed; otherwise, abortion information would be the equivalent of detailed instructions on how to commit a tort, and such speech could probably be restricted. Information that would result in harm to the recipient, such as instructions on how to commit suicide, presents a different problem. Rational recipients will not act on the basis of such information unless, in fact, it benefits them. For instance, instructions on committing suicide will only be implemented if the benefits of continued life are outweighed by the costs. Thus, the argument for state intervention must be paternalistic, and therefore somewhat problematic under the First Amendment. 
Rust, because both houses passed bills that would allow funding of family planning clinics that provided abortion counseling. 85

Public forum doctrine is another form of subsidy. By giving speakers free use of certain government facilities, we make their speech cheaper. Otherwise, speakers would have to incur the cost of obtaining a forum for their speech. Public forum doctrine prevents the government from discriminating in providing this subsidy. There is little risk that a ban on discrimination will lead the government to withdraw this subsidy rather than include disfavored groups. The occasional threat of an unpopular march or demonstration is unlikely to lead the government to cease constructing or maintaining streets, sidewalks, or parks; those facilities are too much in demand for other purposes. As long as the price is not too high, mandating this type of subsidy makes sense. Doctrinally, this means that speakers should be able to use government property as long as they do not impose an undue cost on the government - a simple approach to public forum doctrine proposed by several commentators but so far rejected by the Court. 86

The public good nature of free speech also appears clearly in public employee cases. Why should a public employee not be held to have waived his First Amendment rights when he takes his job? Why should the employee not be allowed to contract away his speech rights freely? ${ }^{87}$ The answer, again, is that speech about government is a

${ }^{85}$ See Philip J. Hilts, Abortion Counseling Ban is Rejected by Senate, 72-25, N.Y. TIMEs, Nov. 8,1991 , at $B 8$.

${ }^{86}$ In United States v. Kokinda, I Io S. Ct. 3 II 5 (I99o), the Court determined that because the sidewalk adjoining a post office was not a traditional public forum, strict scrutiny was not required to uphold a conviction under a postal regulation that prohibited soliciting contributions on Postal Service property. See id. at 3I20 (plurality opinion). Judge Posner maintains that public forum doctrine is flawed because opening government facilities to expression makes a minimal contribution to the free flow of information. He bases this conclusion on the abundance of other channels of communication open to the media in our country. See Posner, supra note 10, at 52. Posner fails to consider that public forums are often the only place where less affluent groups and individuals can effectively express their message. See William E. Lee, Lonely Pamphleteers, Little People and the Supreme Court: The Doctrine of Time, Place, and Manner Regulations of Expression, 54 GEO. WASH. L. REv. 757, 806 (I986).

${ }^{87}$ In Snepp v. United States, 444 U.S. 507 (I980), the Court held that an employment contract requiring a CIA agent to submit publications about the CIA for prior clearance imposed a valid fiduciary obligation on the agent. See id. at 510 . Judge Easterbrook has defended this decision in economic terms:

We may assume, therefore, that Snepp [the agent] has a First Amendment right to broadcast to the world anything within his knowledge, without anyone's permission. This assumption makes no difference to the case if Snepp can bargain with others about how (or whether) he will exercise this privilege. If Snepp's silence, or a prior submission routine, is worth more to the CIA than speech is worth to Snepp, he will sell his speech rights to the CIA; he receives in exchange a salary higher than he could obtain in employment that did not impose conditions on publication.

Frank H. Easterbrook, Insider Trading, Secret Agents, Evidentiary Privileges, and the Production of Information, I98 I SUP. CT. REV. 309, 345 (citations omitted). Judge Easterbrook, 
public good. In other words, the foregone book royalties of a government employee do not accurately measure the social value of the publication; government employees will sign waivers relinquishing speech rights even when the cost to society is greater than the contractual incentive to the employees. Thus, employees should not be freely allowed to contract away their speech rights, particularly if the employees' speech concerns matters of public significance. ${ }^{88}$ If, however, the employees' speech does not concern some matters of public significance, the information conveyed by the speech has little spillover effect outside the office and hence has scant claim to protection. Notably, the Court has held that the speech of public employees receives substantial protection only on matters of public concern. 89

A superficially similar issue was presented in Cohen $v$. Cowles Media Co. ${ }^{90}$ in which the Court held that a newspaper could be sued on the theory of promissory estoppel for breaching a promise of confidentiality to a news source. ${ }^{91}$ In his opinion for the Court, Justice White held that the paper could properly be held liable because "[t]he parties themselves . . . determine the scope of their legal obligations and any restrictions which may be placed on the publication of truthful information are self-imposed." 92 In dissent, Justice Souter pointed out that freedom of the press is intended to create a better-informed public, not just to benefit the newspaper. ${ }^{93}$ Thus, promises made by

however, does not adequately address the fact that the public's interest in the information about the CIA does not fully translate into royalties or other benefits to the agent and that the agent therefore has an insufficient incentive to "hold out." An accompanying footnote appears to acknowledge this point, but Easterbrook then makes the startling suggestion that the government will take the public interest into account because the "gain not captured by Snepp could be captured by the government througn taxes." Id. at $345 \mathrm{n}$. 134. Yet this suggestion assumes that all social gains are realized in the form of higher taxable income and that the government rationally maximizes its tax revenue (which might be a more plausible assumption in Snepp if the CIA were under the jurisdiction of the Internal Revenue Service).

SS This does not mean that such contracts are always impermissible, but they do require judicial oversight.

s9 See Rankin v. McPherson, 483 U.S. $378,384-87$ (1987); Connick v. Myers, 461 U.S. I 38 , $\mathrm{I}_{43-47}\left(\mathrm{IgS}_{3}\right)$. The analysis of contractual waivers is closely related to the principle that public employees cannot be punished for exercising their freedom of expression. See Posner, supra note 10, at 49-50. If such punishment were allowed, the rational public employee would curtail her speech far below a socially optimal level because she would not take into account the considerable external benefits of her speech. Posner, however, downplays the effect of allowing regulation for two reasons. First, he contends that, regardless of the presence of regulations, few public employees want to speak on political issues. See id. at 49 . Second, he argues that the external benefits of public employees' speech are small because the employees are unlikely to have a large audience. See id. Yet his assumption about the value of the collective contribution of public employees to public debate fails to take into account the sheer number of employees affected by this regulation and their unique access to government information.

90 III S. Ct. 2513 (I991).

91 See id. at 2518 .

92 Id. at 2519 .

93 See id. at $2522-23$ (Souter, J., dissenting). 
the press should not necessarily operate as waivers of First Amendment rights.

As a general proposition, Justice Souter's suspicion of waivers of First Amendment rights is supported by many of the same considerations that prompt courts to deny enforcement of speech restrictions in public employment contracts. Yet Cohen differed from the public employment cases because the contractual restrictions in Cohen ultimately expanded the amount of information available to the public. Promising confidentiality encourages frank disclosure by sources and does so to a greater extent when such promises are generally enforceable than when they are not. ${ }^{94}$ Thus, in the long run, applying promissory estoppel to cases involving promises of confidentiality by members of the press should actually increase the stock of public information. Promissory estoppel provides legal enforcement for the newspaper's promise of confidentiality and makes the promise more credible. Intuitively, it seems clear that the greater credibility of the confidentiality pledge will increase the availability of information from sources and that the increase in information will outweigh the occasional loss caused by the paper's inability to reveal the identities of confidential informants. ${ }^{95}$ It is unnecessary to rely on this intuition, however. If the newspaper takes the contrary view and believes that the increase in credibility is not worth losing the right to disclose sources, it is free to opt out of liability by modifying its assurances to confidential sources. ${ }^{96}$

Under the First Amendment, rules that discriminate on the basis of the content of expression are subject to stricter scrutiny than those that are content neutral. ${ }^{97}$ But why should we be more suspicious of content discrimination? Public choice theory may not be able to provide a definitive answer, but it does suggest some reasons for disfavoring content-based restrictions.

If the government's goal is to limit the quantity of speech in some setting, perhaps because the forum has a limited capacity, it is gen-

94 See Daniel A. Farber \& John H. Matheson, Beyond Promissory Estoppel: Contract Law and the "Invisible Handshake," 52 U. CHI. L. REv. 903, 928-29 (1985) (arguing that, in the context of employment and subcontracting relations, promissory estoppel is applicable when it is socially beneficial for the parties to develop a high degree of trust).

${ }^{95}$ For a more complete discussion, see The Supreme Coutr, I9go Term - Leading Cases, I05 HARV. L. REV. 177, 283 (I99I).

96 For example, reporters might be instructed to tell sources: "We normally do not disclose the identities of confidential sources, but we reserve the right to do so when the editors consider the identity of the source especially newsworthy." It seems unlikely that a newspaper would exercise this option.

97 See Widmar v. Vincent, 454 U.S. 263, 276 (1981); Police Dep't v. Mosley, 408 U.S. 92, 95-96 (1972); Daniel A. Farber, Content Regulation and the First Amendment: A Revisionist Viev, 68 GEo. L.J. 727, 742-43 (1980); Susan H. Williams, Content Discrimination and the First Amendment, 139 U. PA. L. Rev. 615, 616-22 (1991). 
erally preferable to choose a content-neutral method of restriction. ${ }^{98}$ Content-neutral restrictions raise the price of information but allow consumers with the highest demand for information to select the type they want. In contrast, content-based restrictions limit the range of selections, which means that high-demand consumers of restricted varieties of information will be unable to obtain what they want while low-demand consumers of the remaining varieties will still find their favorites available. In other words, content-based restrictions infringe more on consumer choice.

Unlike most of the rest of the analysis in this Commentary, this argument does not depend on the nature of speech as a public good. The same argument suggests that if the government wants to limit ice cream consumption, it should do so by taxing ice cream in general rather than by specifying which flavors should be sold. ${ }^{99}$ Similarly, if the government wants to limit book publication to conserve paper during wartime but wants to minimize distortions of consumer demand, it should limit the paper supply directly and allow the market to allocate that supply. It should not try to limit the types of books to be published. ${ }^{100}$

In First Amendment jurisprudence, restrictions based on viewpoint are especially suspect. ${ }^{101}$ Because they attempt to bias the information available to the public, these restrictions contravene the assumption underlying both the First Amendment and most economic theory that information is normally beneficial. Although this assumption may not be irrebuttable, it should not be rejected without some specific evidence of the harm coming from increased information. Furthermore, even if certain forms of information are harmful, viewpoint restrictions are also likely to have damaging side effects. ${ }^{102}$

For example, suppose that the government seeks to prevent financial panics by banning all negative market-related information, such as reports that the economy is doing poorly. Putting aside the effects

98 See Posner, supra note ro, at I6-I8.

99 The tax revenue could be returned to the public in the form of increased government services, higher welfare payments, or some other government program, as long as the refund was not tied to individual ice cream consumption. The goal of maximizing choice while limiting consumption is furthered no matter what is done with the tax revenue, as long as the return of the revenue is not linked to individual consumption choices.

100 This assumes, however, that the demand for books is roughly proportional to the public benefit derived from books. If not, the government might use the rationing system to reallocate publication toward the areas with the highest public benefit. On the same theory, though, it should also subsidize books in those areas during peacetime.

${ }_{101}$ See City of Renton v. Playtime Theaters, Inc., 475 U.S. 4x, $48-49$ (1986); Perry Educ. Ass'n v. Perry Local Educators' Ass'n, 460 U.S. 37,46 ( 1983$)$; id. at $6 \mathrm{I}-62$ (Brennan, J., dissenting) (citing cases); Geoffrey $\mathrm{R}$. Stone, Anti-Pormography Legislation as ViewpointDiscrimination, 9 HaRv. J.L. \& PUB. PoL'y 46r, $46 \mathrm{I}$ (Ig86).

102 One side effect that accompanies any attempt to regulate harmful speech is the "chilling" of beneficial speech. See supra pp. 569-70. 
such a ban would have on political decisionmaking, the ban may have two side effects. First, it may decrease the incentive of those conveying positive reports to be careful because they need not fear contradiction. Thus, even the availability of reliable positive information will be impaired, and the viewpoint restriction will degrade the value of the information that is available. ${ }^{103}$

Second, even if positive reports remain reliable, some negative information will still be conveyed by the absence of positive reports. For example, if unemployment figures usually are announced on a given day of the month and if negative reports are banned, one could infer that unemployment has increased whenever the newspapers carry no unemployment figures on that day. Readers will still receive negative information, but it will be vague (unemployment must be up, but by an unknown amount). ${ }^{104}$ After all economic reports cease, the public will know that the economy is doing poorly but will be unable to tell whether the economy is in a recession or a full-scale depression. In other words, as long as the distribution of reliable positive information is allowed, negative information remains indirectly available despite the government's efforts. The primary effect of the restriction is to make negative information less specific. ${ }^{105}$ Indeed, censorship may generally cause people to think the market is worse than it really is, and thus the government would be better off guaranteeing the availability of accurate information of any viewpoint. 106

The foregoing arguments are not intended to show that viewpoint discrimination or other content distinctions are always undesirable. They are intended to suggest that these forms of regulation generally have heavier social costs than content-neutral regulation, even if they eliminate an equal volume of information. These social costs are magnified by the public good attributes of information, which also

${ }^{103}$ See Posner, supra note ro, at 17.

104 Similarly, in a totalitarian country, if the state paper stops reporting news of military victories, many people are bound to suspect that a total military disaster has occurred.

105 This is actually an unstable situation. Suppose that the government decides to allow only favorable information to be released. If the situation is only mildly unfavorable, no information will be forthcoming. The public will then attempt to estimate how bad the situation is, and their estimate will probably be worse than the reality. Knowing this, the government will revise its rule to allow disclosure of the facts in mildly unfavorable situations. Under the revised rule, however, when a situation arises in which no information is forthcoming, the public will know that the true situation is worse than mildly unfavorable. Knowing of this public reaction, the government will revise its rule again, and the cycle will continue. Alternatively, the government could avoid this situation by suppressing information even when the situation is somewhat favorable, and thus silence will carry a more ambiguous message. Of course, the effect then is to deprive individuals of even more information.

${ }^{106} C f$. George J. Stigler, An Introduction to Privacy in Economics and Politics, $9 \mathrm{~J}$. LegaL STud. 623,626 (1980) (noting that even a person with a poor credit history has an incentive to allow creditors access to her credit record because otherwise creditors will infer that her credit is terrible). 
reduce the political pressure on legislatures to seek efficient regulatory techniques. Perhaps the most important point is that content distinctions in general, and viewpoint discrimination in particular, heighten the lerislature's ability to focus regulation on the most politically vulnerable information sources. ${ }^{107}$ Thus, a higher level of scrutiny is justified to ensure that content regulations are not unnecessarily used. 108

\section{The Role of SELF-EXPREsSION}

Why are we reluctant to think that speech is special, not because it has unique value, but because it is a public good like many others and therefore is underproduced? Why do we tend to see speech as a matter of self-expression rather than economics? In part, self-expression serves as a substitute for economic reward. Some people produce speech despite inadequate economic rewards because they feel strongly about something; that is, they get noneconomic rewards for their efforts. In a society in which financial incentives usually play a central role, these people must want to speak so badly that they are willing to go to a lot of trouble without much tangible reward. If lawyers and doctors received poverty wages, we would expect that most people choosing careers in these fields had powerful ideological motivations and viewed the fields not just as jobs, but as outlets for deep spiritual needs. ${ }^{109}$ In such a world, we might well view these professions just as we presently view free speech - as activities involving unique aspects of the self rather than as mere businesses.

The theory of free speech offered here is decidedly "unromantic," partly because it views self-expression not as something particularly desirable in itself but as providing motivation for individuals to engage in socially useful conduct: the production of information. Rather than celebrating personality traits that lead to expressive activities, public choice theory observes that these traits may be undesirable in themselves but are nevertheless socially useful.

${ }^{107}$ See Harry Kalven, The Concept of the Public Fortm, I965 Sup. CT. Rev. I, 29-30 (explaining that an equality requirement makes it politically difficult to restrict speech activities because neutral restrictions will also affect popular activities).

10s These arguments form a partial defense of the rule against content discrimination. At some point, however, a full defense of that rule probably must rely on assumptions either about improper motivation by the government or about the difficulty of determining which viewpoints are valid or which topics are important. In particular, the stringent rule against viewpoint restrictions finds some support in these economic arguments but probably requires additional justifications from other sources.

${ }^{109}$ Of course, there are people of that kind in these fields, but the incentives provided by the market are sufficient to ensure that we do not have to rely on these peculiarly devoted individuals as the major source of legal or medical services. 
At least some aspects of speech doctrine probably are related to our heavy reliance on - to put it bluntly - kooks and cranks (or more kindly put, visionaries and crusaders) as important producers of speech. Kooks and cranks can be expected to do and say many silly, if not obnoxious, things, but we must put up with them in order to spread valuable information. For example, negative information about our society is most likely to be collected and communicated by people with radical, if not revolutionary, aims. Society must tolerate a certain amount of rhetoric about revolution and a good deal of general "foaming at the mouth" to get the other benefits of radicals' activities. 110 If the market provided adequate incentives for sane, sensible people to dedicate their lives to the production of criticisms of society, we could dispense with the contributions of the fanatics and crackpots. As it is, we must tolerate them - which means in practice that the courts must force people to put up with a lot of violent rhetoric ${ }^{111}$ and nasty talk. ${ }^{112}$

In less tendentious terms, the point here is that society must rely on nonfinancial motivations to encourage the production of information. To refer to individuals prompted by these motivations as "kooks" and "cranks" is in part perhaps an ironic comment on a society in which financial rewards seem increasingly dominant and in which individuals who eschew those rewards are seen as irrational. The nonfinancially motivated producers of information include dedicated scholars, upstanding idealists, and insightful social critics (although we might not all agree on who belongs to these groups). Our willingness to include individuals in these groups, however, may well turn in part on how congenial we find their ideologies. In any event, it is important to recognize that even individuals whom we do not perceive as morally uplifting, personally appealing, or intellectually admirable nevertheless perform a valuable social role.

The facts presented in Rankin v. McPherson ${ }^{113}$ illustrate the reasons for tolerating what might be considered offensive speech by intemperate individuals. McPherson, a clerk in a county constable's office, was fired for remarking to a co-worker, after hearing of an

110 These forms of expression have the incidental benefit of conveying information about the speakers and their motivations, and they add to the shock value of 'speech, which may mean that the related ideas will receive greater circulation.

${ }^{111}$ See, e.g., Brandenburg v. Ohio, 395 U.S. 444,447 (1969) (holding that the First Amendment prohibits a state from proscribing speech that advocates the use of force or lawless activity unless such speech is "directed to inciting or producing imminent lawless action and is likely to incite or produce such action").

112 See, e.g., Cohen v. California, 403 U.S. 15, 26 (1971). But cf. FCC v. Pacifica Found., 438 U.S. 726,746 ( 1978 ) (opinion of Stevens, J.) (noting that "[s]ome uses of even the most offensive words are unquestionably protected" but holding that the FCC may limit the use of such words on the radio to times when children generally are not in the audience).

113483 U.S. $378(1987)$. 
attempt on President Reagan's life, "[I]f they go for him again, I hope they get him."114 A sharply divided Court, over a strong dissent from Justice Scalia, ${ }^{115}$ held that the county had violated the First Amendment. ${ }^{116}$ The Court was correct in finding the speech constitutionally protected. The statement conveyed an important idea (that Reagan was a terrible president) and a significant bit of data about the intensity of at least one person's views. These views were stated only in conversation and thus reached only a very small audience, but cumulatively such private discussions provide an important method of transmitting ideas.

In dissent, Justice Scalia argued, with some plausibility, that a government agency should not have had to put up with an employee whose values were so far out of line with its mission. ${ }^{117}$ Obviously, to the extent that an individual does not share an agency's basic view of its own mission, the agency potentially sacrifices efficiency by keeping that individual as an employee. On the other hand, such disaffected individuals are the most likely to generate criticisms of the agency and to leak important information. In contrast, reasonable, temperate, and well-balanced individuals - good bureaucrats, in other words - are likely to have too much sense to make hostile public statements about their superiors. It is, therefore, in the public interest to require the agency to put up with cranky, ill-mannered, and obstreperous individuals (or brave, courageous, and honest people, depending on one's viewpoint) to a greater extent than the agency would like. ${ }^{118}$ If the agency can fire anyone who makes an offensive, angry comment, many of these potential sources of news and criticism will be silenced.

Because the economic rationale for freedom of speech is based on the information content of speech, it may seem to open the door to distinctions between types of speech based on the social importance of the expressive content of the speech. Thus, it may suggest that speech about important social issues would receive more protection than speech on matters of lesser social concern. This argument should be treated warily for two reasons. First, reasonable people can disagree about the social value of certain speech. There is an obvious

114 Id. at $380-82$.

115 See id. at 394-40r (Scalia, J., dissenting).

116 See Rankin, 483 U.S. at 392.

${ }^{11 i}$ See id. at 399-402 (Scalia, J., dissenting). Justice Scalia stated that the First Amendment does not require an employer to permit employees to "ride with the cops and cheer for the robbers." Id. at 394 (quoting Brief for Appellant at 94 (No. 85-2068)). He argued that such a rule would allow, for example, "employees of the [EEOC] . . . to make remarks on the job approving of racial discrimination." Id. at 400-0I.

11: Again, the theory explains why courts should balance agency efficiency against the potential public benefits of speech, but it does not provide much guidance on the precise contours of the balancing test. See supra pp. 568-69. 
risk that judicial determinations of the social importance of various topics will merely reflect prejudice or ideology.

Second, even if we are confident that firm assessments of value can be made regarding some types of speech, economic linkages may make it difficult to regulate "low-value" speech without reducing the availability of "high-value" speech. ${ }^{119}$ To ensure the wide dissemination of valuable information, the Constitution must protect the frivolous entertainment with which information is often packaged. The entertainment component of certain items containing information may be closer to being a standard consumer good than a public good. Indeed, producers will tend to package the two together to reduce the problem of free riders.

Gratuitous displays of sex and violence in the media provide a useful example. To some observers, these displays lack any social value. Those with a different ideology, however, may view them as conveying an important social message. We might have some qualms, therefore, about the ability of judges to classify forms of speech properly. Moreover, even if the displays themselves do not have positive value, their existence may enable the media to remain economically viable and to present other, more valuable messages. Such material provides a method of cross-subsidizing the protection of other information. Like the previous observation about the motivation of speakers, this phenomenon suggests that we should be prepared to tolerate a great deal of low-level babble as the necessary price for transmitting potentially valuable information. It also suggests that, although society need not tolerate nudity on the streets or in bars, even gratuitous nudity sometimes may serve a useful purpose by fostering demand for media and theatrical performances that have other social value.

Although the economic theory of free speech places no special intrinsic value on self-expression, the theory does illuminate why selfexpression is a useful social value. A society that ("irrationally") places an intrinsic value on speech will, in fact, produce more economically rational results, because individuals will feel compelled to express themselves even when the market fails to provide adequate compensation. They may persevere even in the face of obstacles that would make a more rational person flee for cover. Moreover, legislatures that value self-expression will help counter the natural political imbalance in favor of regulating speech. Judges who value self-expression will remind themselves that the market value of speech to the speaker is not the measure of the speech's true value.

119 For example, if Playboy carries valuable articles, the availability of those articles might be restricted if Playboy's use of nude photographs were banned. The centerfold may crosssubsidize the articles. 
The foregoing analysis of speech as a public good can be put into a broader, noneconomic perspective. The theory focuses on the mismatch between the private motives of speakers and the public benefits of speech. That is, the theory suggests that the special quality of speech is not its relationship to the private self of the speaker, but its relationship to the welfare of the community. It is the communal benefits derived from speech that justify greater protection for speech than for other forms of personal activity. In this respect, the theory's implications are communitarian and republican rather than libertarian and individualistic - perhaps a surprising result for an economic analysis. ${ }^{120}$ Of course, as I remarked at the outset, the public choice outlook on the First Amendment should not be regarded as exclusive. Even the public choice viewpoint recognizes the benefits that accrue to society from giving credence to other theories of free speech and from valuing expression in itself. From the public choice perspective, the individualistic self-expression theory of speech is a myth, but a valuable one.

120 Such a communal vision of speech occasionally appears in First Amendment jurisprudence. For example, in New York Times Co. v. Sullivan, 376 U.S. 254 (1964), the Court stated that a citizen has a duty, not just a right, to criticize government officials. See id. at 268 (citing Beauharnais v. Illinois, 343 U.S. $250,263-64$ \& n.I 8 (1952)). The Court has also given occasional attention to the public benefits of free speech in discussions of the right to receive information. See, e.g., Virginia State Bd. of Pharmacy v. Virginia Citizens Consumer Council, Inc., 425 U.S. 748, 764-65 (I976); Red Lion Broadcasting Co. v. FCC, 395 U.S. 367,390 (I969); Stanley v. Georgia, 394 U.S. 557, 560-64 (1969). For a thorough discussion of the Supreme Court's treatment of the right to receive information, see William E. Lee, The Supreme Court and the Right to Receive Expression, 1987 Sup. Ct. Rev. 303. 